\title{
BAZNAS KABUPATEN GRESIK DAN STRATEGI PENDEKATAN PUBLIC RELATIONS DALAM PENINGKATAN ZISWAF
}

\author{
Hanadi Sirajuddin Munir Baidowi \\ Gresik \\ nad_ninetygirl@yahoo.com
}

\begin{abstract}
A good zakat management requires both professional management and socialization. In 2016 the target achieved by BAZNAS Gresik Regency was 5 billion. This number is still small compared to the potential for compulsory zakat in East Java, which is around 15 trillion. If we look more closely, the muzakki in BAZNAS Gresik Regency are mostly civil servants. This is seen in contrast to the vision of BAZNAS zakat socialization which is aimed at increasing public awareness in general, not only for civil servants. The results of this study are: first, the steps taken by BAZNAS in Gresik Regency in increasing the number of muzakki are to approach the local government; second, the Gresik Regency BAZNAS strategy in increasing the number of muzakki, among others, makes Gresik Regency BAZNAS a reckoned organization, as a zakat service center for a populist community; third, prioritizing the public relations approach by optimizing zakat income and generating ziswaf by installing banners, stickers, online zakat websites, social media, as well as by establishing partnerships with a number of electronic media and conducting counseling/audiences.
\end{abstract}

\section{Keywords: Muzakki, Zakat, Infaq and Shodaqah}

Abstrak: Suatu pengelolaan zakat yang baik membutuhkan manajemen yang profesional begitu juga dalam sosialisasi. Pada tahun 2016 target yang dicapai BAZNAS Kabupaten Gresik adalah 5 milyar, jumlah ini masih kecil dibandingkan potensi wajib zakat yang ada di Jawa Timur yaitu sekitar 15 triliun. Apabila dicermati lebih dalam, sebagian besar muzakki yang ada di BAZNAS Kabupaten Gresik adalah dari Pegawai Negeri Sipil. Hal ini terlihat kontras apabila melihat visi sosialisasi zakat BAZNAS yang ditujukan kepada peningkatkan kesadaran Masyarakat secara umum bukan hanya kepada PNS. Hasil penelitian ini adalah bahwa pertama, langkah-langkah yang dilakukan BAZNAS Kabupaten Gresik dalam meningkatkan jumlah muzakki adalah melakukan pendekatan terhadap pemerintah daerah. Kedua, Strategi BAZNAS Kabupaten Gresik dalam meningkatkan jumlah muzakki antara lain menjadikan BAZNAS Kabupaten Gresik sebagai organisasi yang diperhitungkan, sebagai pusat pelayanan zakat untuk masyarakat yang populis. Ketiga, Mengedepankan pendekatan Public Relation dengan mengoptimalkan pendapatan zakat serta melakukan generate ziswaf dengan memasang spanduk, sticker, website zakat online, media sosial, maupun dengan menjalin partnership dengan sejumlah media elektronik serta melakukan penyuluhan/audiensi.

Kata Kunci: Muzakki, Zakat, Infaq dan Shodaqah

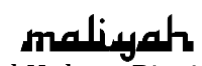

Jurnal Hukum Bisnis Islam

Volume 9 Nomor 2, Desember 2019

p-ISSN: 2088-4869/ e-ISSN: 2597-4351 


\section{Pendahuluan}

Zakat sebagai satu bagian dari rukun Islam merupakan salah satu pilar dalam membangun perekonomian umat. Dengan demikian, salah satu alternatif dalam memecahkan masalah untuk keluar dari kemiskinan adalah dengan optimalisasi pengelolaan dana zakat secara amanah dan komprehensif serta pemanfaat dana zakat untuk kemaslahatan ummat. Selain itu, zakat juga merupakan salah satu dari lima nilai instrumental yang strategis dan sangat berpengaruh pada tingkah laku ekonomi manusia dan masyarakat serta pembangunan ekonomi umumnya. ${ }^{1}$ Tujuan zakat tidak sekedar menyantuni orang miskin secara konsumtif, tetapi mempunyai tujuan yang lebih permanen yaitu mengentaskan kemiskinan. ${ }^{2}$

Tentunya potensi yang sangat besar ini dapat dijadikan sebagai upaya bagi pengentasan kemiskinan dan peningkatan kesejahteraan masyarakat terutama kelompok masyarakat kurang mampu. Pada dasarnya suatu zakat memang bisa disalurkan secara langsung kepada personal (mustahiq zakat). Zakat akan lebih memiliki implikasi ekonomis apabila zakat dikelola oleh suatu lembaga, baik lembaga tersebut didirikan oleh pemerintah maupun kelompok masyarakat. Dalam perspektif nasional, kehadiran badan amil zakat disamping bersifat keagamaan, juga ditempatkan dalam konteks cita-cita bangsa, yaitu membangun masyarakat yang sejahtera, adil dan makmur. Dengan demikian, melalui lembaga zakat kelompok lemah dan kekurangan tidak lagi merasa khawatir akan kelangsungan hidupnya, karena substansi zakat merupakan mekanisme yang menjamin kelangsungan hidup mereka di tengah masyarakat.

Saat ini pengelolaan zakat telah memasuki era baru, setelah diberlakukannya Undang-Undang Nomor 23 Tahun

\footnotetext{
${ }^{1}$ Ahmad M and Saefuddin, Ekonomi Dan Masyarakat Dalam Prespektif Islam (Jakarta: CV. Rajawali, 1987).71

2 Abdurrachman Qadir, Zakat (Dalam Dimensi Mahdah Dan Sosia) (Jakarta: Raja Grafindo Persada, 2001).83-84
} 
2011 tentang Pengelolaan Zakat. Dalam undang-undang tersebut, semua urusan zakat hanya boleh dilakukan oleh badan amil zakat resmi yang dimiliki oleh pemerintah. Hal ini berdasar kepada pertimbangan luasnya jangkauan dan tersebarnya umat Islam di seluruh wilayah Indonesia serta besarnya tugas dan tanggung jawab BAZNAS dalam mengelola zakat, maka dalam pelaksanaan pengumpulan zakat, pemerintah juga membentuk Baznas Provinsi dan Baznas Kabupaten/Kota.

Sesuai dengan tingkat dan kedudukannya, BAZNAS dapat membentuk Unit Pengumpulan Zakat (UPZ) pada lembaga negara, kementerian/lembaga pemerintahan non kementerian, badan usaha milik negara, perusahaan swasta nasional dan asing, perwakilan Republik Indonesia di luar negeri, kantor-kantor perwakilan negara asing/lembaga asing, dan masjid-masjid. Selain itu, dalam pelaksanaan pengelolaan zakat masyarakat juga dapat membantu BAZNAS untuk melakukan pengumpulan, pendistribusian dan pendayagunaan zakat dengan membentuk LAZ. Pemerintah Kabupaten Gresik khususnya pengelola BAZNAS Kabupaten Gresik meyakini akan potensi zakat yang begitu besar di Kabupaten Gresik, karena mereka menilai bahwa masyarakat kota Gresik yang dikenal sebagai masyarakat santri.

Kepercayaan masyarakat Gresik kepada BAZNAS Kabupaten Gresik cukup besar. Hal ini bisa dilihat dari data BAZNAS Kabupaten Gresik, dimana muzakki yang paling rendah adalah pada tahun 2010 dimana muzakki hanya berjumlah 100 orang kemudian mengalami kenaikan sampai pada tahun 2016 dapat dilihat pada tabel di bawah.

Tabel 4.1

Data Jumlah Muzakki Tahun 2010-2016 


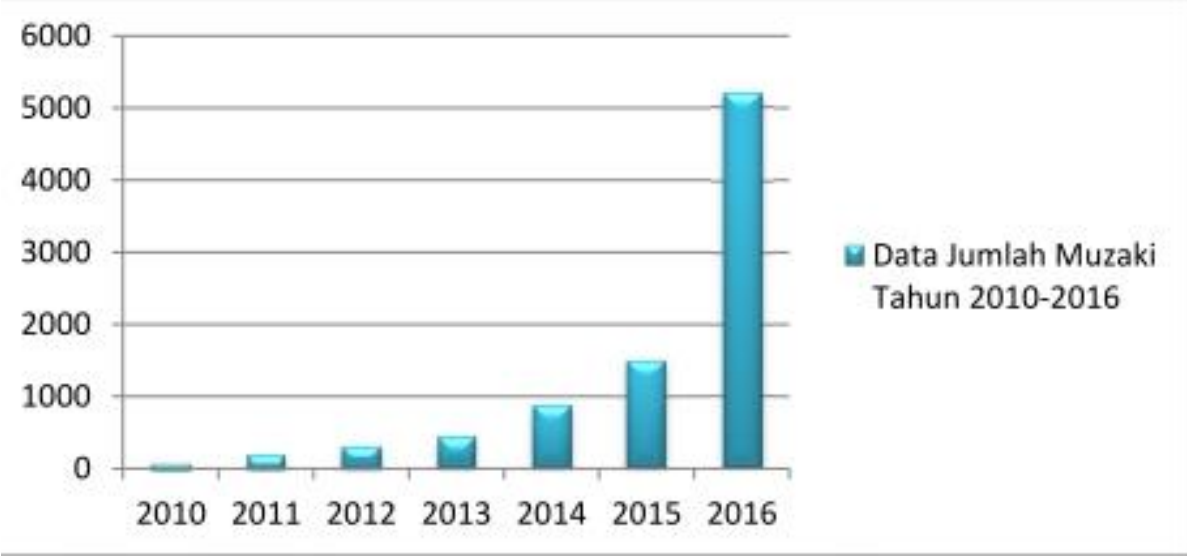

Dari tabel di atas bisa kita lihat bahwasanya peningkatan muzakki dari tahun 2015 ke 2016 meningkat sangat signifikan.Walaupun jumlah muzakki mengalami peningkatan setiap tahun, namun peningkatan kepercayaan masyarakat non PNS masih sangat minim. hal ini dapat ditunjukan pada tingkat penurunan yang sangat tajam muzakki yang berasal dari perusahaan.

Tabel 4.2 Data Perolehan Zakat dari PNS dan Perusahaan. ${ }^{3}$

\begin{tabular}{|l|l|l|}
\hline Tahun & $\begin{array}{l}\text { Zakat Personal } \\
\text { (PNS) }\end{array}$ & $\begin{array}{l}\text { Zakat } \\
\text { Perusahaan }\end{array}$ \\
\hline 2015 & $780.871 .150,-$ & $1.309 .573 .016,-$ \\
\hline 2016 & $1.434 .173 .974,-$ & $10.000 .000,-$ \\
\hline
\end{tabular}

Besarnya potensi tidak menafikan rendahnya nominal zakat yang terhimpun. Hal ini terjadi karena masyarakat khususnya warga Kabupaten Gresik yang belum terbiasa memberikan zakatnya kepada lembaga/yayasan amal yang dikelola pemerintah atau swasta, karena tidak adanya transparansi dalam laporan penyaluran, sehingga masyarakat tidak tahu secara rinci kemana dana tersebut disalurkan serta kurangnya pendekatan dan sosialisasi dari pihak BAZNAZ Gresik kepada masyarakat. Hal ini dikarenakan beberapa faktor

3 BAZNAZ Kabupaten Gresik, Laporan Pertanggung Jawaban BAZNAZ Kabupaten Gresik (Gresik, n.d.).12 
antara lain; Pertama, jenis zakat yang dihimpun pada umumnya adalah zakat fitrah. Kedua, belum adanya kesadaran kaum muslimin untuk berzakat. Ketiga, kebiasaan masyarakat yang langsung menyalurkan zakat kepada mustahiq tanpa perantaraan amil zakat. Keempat, lembaga amil zakat belum dikelola secara profesional dan hanya bekerja pada bulan ramadhan, tidak sepanjang tahun. ${ }^{4}$

Banyak praktisi akademisi yang mulai menyadari bahwa penekanan yang diberikan dalam aktifitas pemasaran sebaiknya tidak hanya dilakukan pada proses untuk melakukan transaksi saja, namun harus tetap memiliki hubungan dengan pelanggannya. Hal ini yang menjadi dasar konsep pemasaran relasional yang saat ini mulai diterapkan oleh pengelola Badan Amil Zakat Nasional (BAZNAS) secara modern supaya berkembang dan memberikan manfaat yang lebih bagi masyarakat.

Melihat upaya yang dilakukan dalam pengelolahan ZIS, sudah seharusnya masyarakat muslim di Kabupaten Gresik sebagai muzakki untuk lebih tergerak lagi dalam membayar zakat, infaq dan shodaqoh (ZIS) melalui BAZNAS Kabupaten Gresik. Menjadi sesuatu yang menarik untuk diteliti, pengelola BAZNAS Gresik menggunakan pendekatan public relation pada muzakki agar mampu meningkatkan jumlah muzakki dan zakatnya serta apa saja yang telah mereka lakukan dalam upaya menjaga dan menumbuhkan jumlah muzakki dan zakatnya demi tercapai kesejahteraan masyarakat Indonesia khususnya di Gresik.

Dari uraian latar belakang di atas ada beberapa permasalahan yang perlu dibahas dalam penelitian ini, seperti: bagaimana kesadaran muzakki dalam mengeluarkan zakat, infaq dan sodaqah di Gresik? bagaimana strategi BAZNAS Gresik dalam meningkatkan jumlah muzakki? dan bagaimana efektifitas pendekatan public relations BAZNAS pada peningkatan kesadaran muzakki di Gresik?

${ }^{4}$ Ibid.13

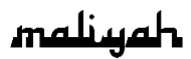




\section{BAZNAS Kabupaten Gresik}

BAZNAS (Badan Amil Zakat Nasional) Gresik bermula dari usulan kepala Kantor Departemen Agama Kabupaten Gresik kepada Bupati Gresik yang dalam pendiriannya mengalami keterlambatan karena terbentuknya BAZ Gresik itu sendiri menurut Kasi Penyelenggaraan Zakat dan Wakaf pada Kantor Depag Gresik adalah akibat adanya desakan dari kepala Kantor Departemen Agama Pusat (Jakarta) dalam rangka implementasi Undang-Undang Nomor 38 Tahun 1999 tentang Pengelolaan Zakat, sehingga dibentuklah BAZ Kabupaten Gresik yang bersekretariat di Kasi Penyelenggaraan Zakat dan Wakaf pada Kantor Depag Gresik, namun mengalami kefakuman sampai akhirnya dibentuk kembali pada tahun 2008 melalui SK Bupati Gresik Nomor 451/411/HK/403.14/2008 tentang BAZ (BAZ) Periode 20082011, yang kemudian diubah dengan SK Bupati Gresik Nomor 451/411/HK/437.12/2009 tentang Perubahan atas Keputusan Bupati Gresik Nomor 451/411/HK/403.14/2008 tentang BAZ (BAZ) Periode 2008-2011.5

Awalnya, BAZ ini berkantor atau nebeng di ruang kesekretariatan Kasi Penyelenggaraan Zakat dan Wakaf pada Kantor Depag Kabupaten Gresik, kemudian sejak bulan Juni 2010 lalu bersamaan dengan menyongsong Ramadlan $1431 \mathrm{H}$, BAZ Gresik mensosialisasikan keberadaan kantor barunya yang sampai sekarang bertempat di kantor secretariat di Masjid alInabah di lingkungan kantor Pemda Gresik Jalan Dr. Wahidin Sudirohusodo Nomor 245 Telp. (031) 395 2825-30 Pst. 031-70 334535 Gresik 61161.

Disamping itu, BAZ Gresik juga menerbitkan Bulletin sebagai media informasi dan silaturrahim dengan nama Bulletin BAZ Kabupaten Gresik yang edisi perdana (Edisi 1Ramadlan 1431 H/Agustus 2010 M) telah diterbitkan dan diharapkan dapat menjadi media komunikasi antara muzakki dengan pengelola, pengelola dengan mustahiq maupun muzakki

5 "Sejarah BAZNAZ Gresik," http://baznasgresik.com/sejarah/. 
dengan mustahiq secara langsung dalam pengembangan wawasan, informasi tentang kegiatan kelembagaan dan pendayagunaan potensi zakat yang ada di Kabupaten Gresik.

Dalam menjalankan tugasnya, lembaga Baznas Gresik memiliki visi dan misi yang visinya adalah "Meningkatkan taraf hidup menuju masyarakat Gresik yang Bertaqwa, Cerdas dan Sejahtera." Maka BAZ Gresik bertekad untuk mewujudkan misi yang telah dirumuskan bersama yaitu: mewujudkan organisasi BAZ yang Transparan, Amanah dan Profesional; mendorong berbagai usaha pengembangan ekonomi produktif yang berkelanjutan; memadukan potensi jaringan antara BAZ/LAZ untuk menjadi kekuatan menyatukan strategi pemberdayaan melalui pengelolaan; melakukan upaya oengembangan SDM dalam bidang pengelolaan BAZ.

Baznas Gresik merupakan lembaga pengumpul zakat di wilayah Kabupaten Gresik yang secara legal formal memiliki kewenangan sangat luas yaitu melingkupi seluruh perusahaan atau instansi (SKPD) di wilayah Kabupaten Gresik. Hal ini sesuai dengan tujuan didirikannya lembaga ini yaitu:

1. Meningkatkan kesadaran masyarakat dalam penunaian dan pelayanan ibadah zakat,

2. Meningkatkan fungsi dan peranan pranata keagamaan (zakat) dalam upaya mewujudkan kesejahteraan masyarakat dan keadilan sosial, dan

3. Meningkatkan hasil guna dan daya zakat.

Adapun manfaat apabila zakat dikelola secara benar oleh Negara (dalam hal ini pemerintah Kabupaten Gresik), menurut ketua MUI Kabupaten Gresik antara lain:

1. Kelompok masyarakat yang lemah dan kekurangan tidak merasa hidup di belantara, tempat berlakunya hukum rimba, dimana yang kuat menindas yang lemah. Sebaliknya mereka merasa hidup ditengah manusia yang beradab, memiliki nurani, kepedulian antara sesame dan tradisi saling tolongmenolong serta memperkuat tali ukhuwah Islamiyyah.

2. Para muzakki lebih disiplin dalam menunaikan kewajibannya dan kaum fakir miskin lebih terjamin haknya. 
Dengan adanya petugas resmi yang bertugas memungut zakat dari para wajib zakat (muzakki) setiap tahunnya akan menjadikan para muzakki lebih disiplin membayar zakat sesuai dengan ketentuan syariat Islam. Apalagi pemerintah selaku pengelola zakat, melengkapi diri dengan peraturan-peraturan yang berisi ketentuan-ketentuan tertentu, misalnya sanksi dan hukuman bagi muzakki yang enggan membayar zakat.

\section{Komunikasi dan Public Relations}

Berkomunikasi yang baik dan efektif akan menghasilkan keuntungan yang tinggi. Komunikasi dua arah yang efektif harus dipandang sebagai satu-satunya alat manajemen public relations yang dimanfaatkan dalam mengembangkan organisasi. Bagi public relations, umpan balik lewat opini publik yang diciptakan akan membawa perbaikan, perubahan dan perkembangan sebagai efeknya. Cara yang paling bernilai dan bermanfaat adalah adanya sikap terbuka untuk menerima umpan balik melalui pemantauan pihak-pihak yang terkait.

Komunikasi yang efektif adalah penerimaan pesan oleh komunikan (receiver) sesuai dengan pesan yang dikirim oleh komunikator (sender), kemudian komunikan memberikan respon yang positif sesuai dengan yang diharapkan. Suatu komunikasi dapat dikatakan efektif apabila mencakup lima kriteria, yaitu pemahaman, kesenangan, pengaruh pada sikap, hubungan yang semakin baik dan tindakan. ${ }^{6}$

Agar komunikasi dapat berjalan secara efektif, Wilbur Schramm ${ }^{7}$ menampilkan apa yang ia sebut "the condition of success in communication", yakni kondisi yang harus dipenuhi jika kita menginginkan agar suatu pesan membangkitkan tanggapan yang kita kehendaki. Kondisi tersebut dapat dirumuskan sebagai berikut:

\footnotetext{
${ }^{6}$ Deddy Mulyana, Metodologi Penelitian Kualitatif (Bandung: PT Remaja Rosdakarya, 2002).22

${ }^{7}$ Onong Effendy, Ilmu Teori Dan Filsafat Komunikasi (Bandung:

PT.Rosdakarya, 2000).41
} 
1. Pesan harus dirancang dan disampaikan sedemikian rupa, sehingga dapat menarik perhatian komunikan.

2. Pesan harus menggunakan lambang-lambang tertuju kepada pengalaman yang sama antara komunikator dan komunikan, sehingga sama-sama mengerti.

3. Pesan harus membangkitkan kebutuhan pribadi komunikan dan menyarankan beberapa cara untuk memperoleh kebutuhan tersebut.

4. Pesan harus menyarankan suatu jalan untuk memperoleh kebutuhan yang layak bagi situasi kelompok di mana komunikan berada pada saat ia digerakkan untuk memberikan tanggapan yang dikehendaki.

Bagi public relations, dalam melaksanakan fungsi dan kegiatannya berpusat pada komunikasi. Komunikasi memiliki peran yang besar dalam Public Relations di antaranya: ${ }^{8}$

1. Komunikasi dalam public relations merupakan titik sentral.

2. Dalam setiap proses komunikasi, hubungan kemanusiaan merupakan proses yang menyangkut kepribadian, sikap dan tingkah laku yang terjadi pada orang-orang yang terlibat.

3. PR dalam fungsinya melaksanakan komunikasi persuasif dua arah di semua bidang kegiatan dengan maksud memberi motivasi kerja, bertanggung jawab dan produktif.

4. Atas dasar pengertian tersebut, terlihat bahwa komunikasi timbal balik dalam public relations merupakan proses integrasi antarmanusia, bukan hanya hubungan antarmanusia (human relations) saja.

Menurut James E. Grunig, dalam perkembangan Public Relations dalam konsep dan praktik dalam proses komunikasi terdapat empat model (four typical ways of conceptual and practicing communication), yaitu: ${ }^{9}$

1. Model Publicit or Press Agentry

2. Model Public Information

\footnotetext{
${ }^{8}$ Sr. Maria Assumpta Rumanti, Dasar-Dasar Public Relations Teori Dan

Praktik (Jakarta: PT. Grasindo, 2002).86

${ }^{9}$ Rosady Ruslan, Metode Penelitian PR Dan Komunikasi (Jakarta: PT.

RajaGrafindo, 2003).103
} 


\section{Model Two Way Asymmetrical}

4. Model Two Way Symmetrical

Dalam Sistem Pelayanan Pelanggan Online Realtime (SPPOR) ini, model komunikasi Public Relations yang digunakan adalah model two way asymmetrical. Pada model komunikasi ini, PR melakukan kampanye melalui komunikasi dua arah dan penyampaian pesan-pesan berdasarkan hasil riset serta strategi komunikasi persuasif publik secara alamiah (scientific persuasive). Unsur kebenaran informasi diperhatikan untuk membujuk publik agar mau bekerja sama, bersikap terbuka sesuai harapan perusahaan. Dalam model ini, masalah 'feedback' dan 'feedforward' dari pihak publik diperhatikan, serta berkaitan dengan informasi mengenai khalayak diperlukan sebelum melaksanakan komunikasi. Maka, kekuatan membangun hubungan (relationship) dan pengambilan inisiatif selalu didominasi oleh si pengirim (sources). ${ }^{10}$

Gambar II.1

Model two way asymmetrical Communication with persuasive aim Two Way Communication Feedback from or feedforward
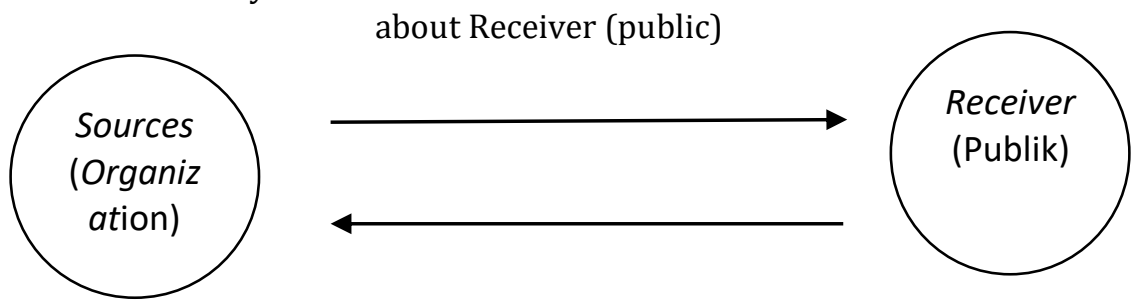

Inilah yang dimaksud dengan komunikasi dalam PR yang selalu merupakan komunikasi timbal balik demi kepentingan semua pihak.

\section{Kesadaran Muzakki dalam Mengeluarkan Zakat, Infaq dan Sodaqoh di Gresik}

Upaya BAZNAS Kabupaten Gresik untuk mencapai secara optimal melakukan beberapa hal antara lain: Program jemput bola, dengan program layanan jemput ZIS, BAZNAS

10 Ibid.104 
Kabupaten Gresik mendatangi muzakki, munfiq dan mustah\}iq untuk mengambil dana ZIS yang sudah disiapkan. Dengan ini tidak akan merepotkan bagi muzakki, munfiq dan mustah\}iq untuk datang ke kantor pelayanan Sekretariat BAZNAS Kabupaten Gresik ataupun transfer melalui Rekening BAZNAS Kabupaten Gresik. Selain itu ada pula program mempertemukan muzakki, munfiq dan mustahiq dengan berbagai event misalnya sosialisasi gerakan infak bulanan dan gerakan zakat profesi. Pada saai itu muzakki, munfiq dan mustah\}iq secara langsung manjadi kesaksian agar timbul kepercayaan pada lembaga dan tergugah akan menunaikan zakat melalui BAZNAS.

Pada bulan Mei 2011, BAZNAS Kabupaten Gresik menyelenggarakan program Gresik Cerdas dengan memberikan beasiswa kepada dhuafa yang berprestasi di lembaga pendidikan mulai tingkat SD/MI, SLTP/MTs, SLTA/MA/SMK. Adapun program kerja lebih detailnya sebagai berikut:

1. Gresik Cerdas. Contohnya pemberian bantuan dana pendidikan yang bersifat konsumtif dan insidentil bagi siswi sekolah formal dan santri pondok pesantren, serta pemberian bantuan dana pendidikan yang berkelanjutan.

2. Gresik Sehat. Berupa bantuan biaya pengobatan bagi masyarakat yang tidak mampu. Pengobatan gratis bagi masyarakat yang tidak mampu.

3. Gresik Berdaya. Antara lain berupa bantuan ternak bergulir, bantuan modal bergulir serta bantuan alat kerja.

4. Gresik Peduli. Antara lain berupa bantuan kepada anak yatim/piatu dan duafa, bantuan kepada musibah bencana alam, bantuan kepada muallaf, bantuan kepada ibnu sabil/musafir, bantuan kepada garimin, pengadaan ambulance gratis, serta bantuan perbaikan rumah gakin.

5. Gresik Taqwa. Antara lain berupa bantuan sosial keagamaan di luar delapan asnaf seperti bantuan sarana ibadah dan kegiatan keagamaan, bantuan kepada guru ngaji, hafiz/hafizah, imam rawatib serta muadzin. Dana 
infaq dan sadaqah banyak disalurkan dalam program Gresik Taqwa.

Selain itu, dalam bidang pengembangan, BAZNAS Kabupaten Gresik mempunyai beberapa langkah program diantaranya pertama, membuka layanan konsultasi ZIS, Adanya layanan konsultasi ZIS diharapkan mampu memberikan pemahaman terhadap masyarakat yang masih belum mengerti tentang pentingnya zakat, serta diharapkan mampu memberikan peningkatan untuk sadar zakat kepada para wajib zakat (muzakki). Kedua, Peningkatan SDM Amil melalui beberapa pelatihan, seperti: pelatihan jurnalistik bagi pengelola majalah "Tazkiyah", pelatihan Tenaga Pendamping Pemberdayaan Masyarakat Miskin, yang bekerja sama dengan LSM "SAGAF" (Sunan Giri Foundation), melakukan study banding ke BAZ yang berprestasi. Ketiga Pemberian penghargaan bagi SKPD/UPZ yang berprestasi. Keempat, Study banding/mengundang BAZ/LAZ yang berprestasi dalam pengelolaan ZIS. Kelima, Membentuk desa binaan di tiap kecamatan secara bertahap. Keemam, Membentuk UPZ di sekolah dan perusahaan.

Rencana Strategis BAZNAS Kabupaten Gresik bertujuan menyatukan visi dan misi yang selaras dengan visi dan misi BAZNAS sesuai dengan potensi di Kota Gresik. Untuk merealisasikan visi dan misi tersebut, penting untuk membangun standar pengelolaan zakat agar pengelolaan zakat nasional dapat dilakukan secara optimal baik dalam pengumpulan maupun pendistribusian dan pendayagunaan. Sebagai lembaga pengelola zakat, BAZNAS Kabupaten Gresik mengemban amanah dan tanggung jawab penuh terhadap pengelolaan dana zakat. Dengan berpedoman pada visi dan misi, BAZNAS Kabupaten Gresik merumuskan beberapa rencana strategi untuk mewujudkan berbagai tujuan yang diharapkan.

Dengan demikian, Rencana Strategis ini merupakan panduan dalam pengelolaan yang selaras dengan visi dan misi BAZNAS, BAZNAS Provinsi dan BAZNAS Kab/Kota untuk mewujudkan kebangkitan zakat di Indonesia sehingga tujuan pengelolaan zakat 
nasional sebagaimana yang diamanatkan Undang-Undang dapat tercapai. Dalam hal ini terdapat beberapa rencana strategi, antara lain: menjadikan BAZNAS Kabupaten Gresik sebagai organisasi yang diperhitungkan; menjadikan BAZNAS Kabupaten Gresik sebagai pusat pelayanan zakat untuk masyarakat yang populis; menjadikan BAZNAS Kabupaten Gresik sebagai badan yang mampu melayani kebutuhan masyarakat duafa dan mustahiq dalam segala bidang; menjadikan BAZNAS Kabupaten Gresik sebagai pusat pemberdayaan ekonomi umat; mensejahterakan masyarakat duafa di wilayah Kabupaten Gresik; ,enjadikan motivator bagi muzakki untuk menghitung besar zakatnya.

BAZNAS Kabupaten Gresik memiliki rencana strategi dalam merebut kepercayaan dan perhatian dari para donatur (muzakki), yang kemudian dalam pengumpulan, pendistribusian serta pendayagunaanya BAZNAS Kabupaten Gresik dibantu oleh Unit Pengumpul Zakat (UPZ). Di samping itu, untuk menumbuhkan kesadaran berzakat, baik untuk pegawai institusional pemerintah maupun swasta, pengurus BAZNAS Kabupaten Gresik melakukan berbagai cara diantaranya: memberikan wawasan (know how) yang benar dan memadai tentang zakat, infaq dan sedekah, baik dari segi epistemologi, terminologi maupun kedudukannya dalam segi ajaran Islam; manfaat (benefit) serta hajat (need), dari zakat, infaq dan shadaqah, khususnya untuk pelakunya maupun para mustahik zakat.

\section{Efektifitas Pendekatan Public Relations BAZNAS Pada Peningkatan Kesadaran Muzakki di Gresik}

Suatu program Public Relations dalam menjalankan Strategi, baik itu yang berjangka panjang maupun berjangka pendek, harus direncanakan dengan cermat dan teliti, sedemikian rupa sehingga akan diperoleh hasil-hasil yang nyata. Perencanaan yang matang akan menghasilkan suatu program Public Relations yang efektif. Perencanaan program Public Relations berdasarkan fakta dan landasan berpikir yang sehat, yang membuat seseorang menjadi tahu arah dan tujuan yang ingin dicapainya. Perencanaan program Public Relations 
dalam menjalankan strategi berkaitan dengan Proses Public Relations.

Selain itu dalam bidang pengembangan, BAZNAS Kabupaten Gresik mempunyai beberapa langkah tugas Public Relation, diantaranya pertama, membuka layanan konsultasi ZIS (Counseling), Adanya layanan konsultasi ZIS diharapkan mampu memberikan pemahaman terhadap masyarakat yang masih belum mengerti tentang pentingnya zakat, serta diharapkan mampu memberikan peningkatan untuk sadar zakat kepada para wajib zakat (muzakki). Kedua, Peningkatan SDM Amil melalui beberapa pelatihan, seperti: pelatihan jurnalistik bagi pengelola majalah "Tazkiyah", pelatihan Tenaga Pendamping Pemberdayaan Masyarakat Miskin, yang bekerja sama dengan LSM "SAGAF" (Sunan Giri Foundation), melakukan study banding ke BAZ yang berprestasi. Ketiga, pemberian penghargaan bagi SKPD/ UPZ yang berprestasi. Keempat, Study banding/mengundang BAZ/ LAZ yang berprestasi dalam pengelolaan ZIS. Kelima, membentuk desa binaan di tiap kecamatan secara bertahap. Keemam, membentuk UPZ di sekolah dan perusahaan.

Bagi organisasi seperti badan/lembaga pengelola zakat maka tugas utama untuk lembaga tersebut adalah mencari donatur yaitu para muzakki, munfiq dan mutasadiq. Semakin banyak lembaga pengelola zakat yang bermunculan menyebabkan tingkat kepercayaan muzakki menjadi hal penting untuk dikaji. Hal inilah yang kemudian diperlukan untuk menganalisa faktor-faktor yang mempengaruhi muzakki untuk tetap memberikan kepercayaan kepada BAZNAS Kabupaten Gresik.

Faktor-faktor pendukung kepercayaan muzakki kepada BAZNAS Kabupaten Gresik melalui strategi Pubic Relations antara lain: pertama, pengelola terpercaya dan amanah. Komitmen dari tenaga kerja untuk mengemban amanat dalam menjalankan visi dan misi lembaga menjadikan suatu kekuatan bagi BAZNAS Kabupaten Gresik dalam menjadikan pengelolaan ZIS yang terpercaya dan amanah. Kedua, adanya dukungan dari 
penguasa. Adanya dukungan dari pemerintah dan masyarakat sekitar yang memiliki apresiasi tinggi bukan hanya dalam bentuk dukungan moril akan tetapi juga dengan dukungan materiil.

Penguasaan Pemerintah berpengaruh besar bagi masyarakat menaruh kepercayaan terhadap BAZNAS Kabupaten Gresik. Struktur birokrasi juga dinilai sebagai poin penting dalam peningkatan kesadaran serta kepercayaan dalam berzakat. Melalui Surat Edaran Bupati Nomor 450/157/437.13/2011 tentang Gerakan Infaq Bulanan. Selain itu, Surat Edaran Bupati 450/38/437.13/2012 pada tanggal 9 Pebruari 2012 tentang Gerakan Zakat Profesi

Adapun langkah-langkah strategis yang hingga saat ini dijalankan oleh Public Relations BAZNAS Kabupaten Gresik yaitu di antaranya: pertama, dengan mengoptimalkan sosialisasi informasi BAZNAS melalui media seperti, spanduk, sticker, website zakat online, media sosial, maupun dengan menjalin partnership dengan sejumlah media elektronik serta melakukan penyuluhan/audiensi. Selanjutnya dalam peningkatan jumlah muzakki BAZNAS Kabupaten Gresik melakukan beberapa strategi sebagai berikut:

\section{Pertama, Kebijakan Pemerintah Daerah}

Kebijakan pemerintah daerah dinilai sebagai poin utama dalam peningkatan penghimpunan/pengumpulan (fundraising) menjadi hal utama bagi BAZNAS. Kebijakan ini dilakukan melalui pendekatan kepada Bupati yang pada akhirnya mengeluarkan "surat sakti" yaitu Surat Edaran Bupati Nomor 450/157/437.13/2011 tentang Gerakan Infaq Bulanan dan Surat Edaran Bupati 450/38/437.13/2012 pada tanggal 9 Pebruari 2012 tentang Gerakan Zakat Profesi. Berdasarkan Surat Edaran Bupati Kabupaten Gresik Nomor: 450/157/437.13/2011, tertanggal 14 April 2011 tentang Gerakan Infaq Bulanan yang berisi tentang pemberitahuan sekaligus permohonan kepada seluruh pegawai yang beragama Islam untuk berpartisipasi aktif dalam program tersebut dengan memperhatikan ketentuan- ketentuan sebagai berikut: 1) Gerakan Infaq Bulanan dimaksud 
merupakan himbauan/anjuran dan bukan merupakan kewajiban. 2) Pembayaran infaq dimaksud tidak boleh diambilkan langsung dari gaji pegawai yang bersangkutan (potong gaji), kecuali ada pernyataan dari yang bersangkutan untuk diambilkan dari gaji. 3) Besar infaq ditetapkan menurut golongan kepangkatan sebagai berikut: Golongan I/TKM: Rp. 2.000,00, Golongan II: Rp. 3.000,00, Golongan III : Rp. 6.000,00, Golongan IV: Rp. 10.000,00.

Berdasarkan surat rekomendasi tahun 2013, BAZNAS Kabupaten Gresik memperbaharuai nominal surat Gerakan Infaq Bulanan kepada seluruh PNS, sebagaimana berikut: Golongan I : Rp. 5.000,00, Golongan II : Rp. 10.000,00, Golongan III : Rp. 15.000,00, Golongan IV : Rp. 25.000,00. Selain surat edaran Bupati Gresik tersebut diatas, BAZNAS Kabupaten Gresik juga menginstruksikan kepada para pengumpul zakat dari PNS/ karyawan BUMD di lingkungan Kabupaten Gresik yang telah memiliki penghasilan mencapai nisab agar menyalurkan zakat profesinya senilai 2,5\% kepada BAZ kabupaten Gresik melalui petugas UPZ yang ada. Surat Edaran tersebut di atas dikeluarkan dengan maksud mengharapkan bantuan serta partisispasi kepada karyawan/karyawati di lingkungan Pemerintah Kabupaten Gresik dalam pengumpulan infak bulanan. Akan tetapi, gerakan infak bulanan yang diadakan oleh BAZNAS Kabupaten Gresik masih bersifat himbauan bukan keharusan/kewajiban. Hal ini dibuktikan dengan masih kurang aktifnya SKPD dalam pembayaran infak. Dengan adanya Surat Edaran Bupati tentang Gerakan Infak dan Zakat selama tiga tahun berlangsungnya pengumpulan zakat BAZNAS Kabupaten Gresik meningkat drastis.

Tabel: 4.3

Data PNS Kabupaten Gresik Berdasarkan Agama Perjenis kelamin

\begin{tabular}{|l|l|l|l|l|}
\hline No. & Agamama & Laki-Laki & Perempuan & Jumlah \\
\hline 1. & Islam & 5654 & 5026 & 10680 \\
\hline 2. & Kristen Katolik & 5 & 11 & 16 \\
\hline
\end{tabular}


Baznas Kabupaten Gresik Dan Strategi Pendekatan Public Relations ...

\begin{tabular}{|l|l|l|l|l|}
\hline 3. & Kristen Protestan & 17 & 24 & 41 \\
\hline 4. & Hindu & 5 & 3 & 8 \\
\hline Jumlah & 5681 & 5064 & 10745 \\
\hline
\end{tabular}

Dari data di atas, terlihat potensi pengembangan zakat di BAZNAS Kabupaten Gresik adalah besarnya jumlah muzakki yakni 99\% muzakki dari jumlah PNS yang ada dan mayoritas warga Gresik 90\% beragama Islam.

\section{Kedua: Sosialisasi}

Dalam bersosialisasi, BAZNAS Kabupaten Gresik memberikan pemahaman kepada masyarakat tentang ZIS, hal ini sangatlah tidak mudah dan membutuhkan proses. Keberhasilan ini tergantung pada kesungguhan lembaga dalam mengenalkan ziswaf kepada masyarakat dengan bekerja keras bersama stake holder terkait, baik phak BAZNAS, pemerintah maupun masysrakat sendiri.

Dalam upayanya untuk meningkatkan jumlah muzakki, BAZNAS Kabupaten Gresik melakukan Sosialisasi Sadar Zakat (Building a Constituency), selain itu juga mengadakan Sosialisasi Gerakan Infak Bulanan serta pembinaan Unit Pengumpul Zakat (UPZ) yang ada di masing-masing Satuan Kerja Perangkat Daerah (SKPD). Sosialisasi-sosialisasi tersebut dilakukan dengan cara melalui pemasangan reklame gratis yang dikelola oleh Dinas Pendapatan Daerah (DISPENDA) Kabupaten Gresik, selain itu juga melalui penyebaran brosur dan pemasangan spanduk.

Peran dan fungsi BAZNAS Kabupaten Gresik sebagai amil zakat sangat menentukan dalam keberhasilan manajemen dan pengelolaaan zakat, oleh karena itu BAZNAS Kabupaten Gresik perlu memiliki perencanaan yang matang meliputi penghimpunan, pendistribusian, pencatatan dan pelaporan tentang dana zakat. Karena hal tersebut berkaitan dengan upaya untuk meningkatkan jumlah muzakki dari waktu ke waktu secara terus menerus, artinya jumlah mustahiq akan bertambah dan tentunya hal ini menuntut adanya kesadaran lebih besar dari masyarakat yang mampu untuk menunaikan 
ibadah zakat. Jadi hal tersebut merupakan sebuah tantangan bagi BAZNAS Kabupaten Gresik untuk menghimpun dana dari masyarakat karena BAZNAS sebagai lembaga amil zakat merupakan lembaga yang menjadi mitra bagi pemerintah dalam menanggulangi masalah sosial.

Apabila benar-benar diperhatikan sebenarnya masih banyak masyarakat yang memiliki potensi untuk berzakat. Untuk itu ada baiknya jika BAZNAS Kabupaten Gresik lebih gencar mensosialisasikan diri sebagai lembaga amil zakat nasional dan melakukan sosialisasi tentang gerakan sadar zakat kepada masyarakat, sehingga akan tumbuh motivasi dan keinginan muzakki untuk memberikan sebagian rezekinya dengan ikhlas untuk diberikan kepada orang-orang yang kurang mampu. Hal ini dianggap penting karena bila jumlah muzakki terus bertambah maka dana zakat yang dikumpulkan juga akan semakin bertambah besar jumlahnya, sehingga pengelolaan dana tersebut secara profesional dan amanah akan memberikan arti yang sangat penting bagi pemberdayaan ekonomi umat. Untuk mengoptimalkan peran kepedulian kepada masyarakat khususnya daerah Gresik, BAZNAS Kabupaten Gresik hadir sebagai lembaga yang dituntut untuk selalu meningkatkan kemampuan serta kreatifitasnya dalam rangka mengelola dana kepedulian dari para donatur kepada masyarakat yang membutuhkan. Oleh karena itu dibutuhkan terus menerus berbagai macam bantuan, dukungan serta partisipasi dari banyak pihak dalam mewujudkan peran dan aktifitas BAZNAS Kabupaten Gresik di tengah masyarakat luas khususnya oleh mustahiq.

\section{Ketiga, Jemput zakat bola.}

Sebagai lembaga amil zakat BAZNAS Kabupaten Gresik mempunyai cara tersendiri untuk mengumpulkan zakat, infak dan shadqah dari para muzakki dan donatur. Tekhnik pengumpulan dana zakat, infak dan shadqah yang dilakukan oleh BAZNAS Kabupaten Gresik adalah dengan tekhnik jemput bola, yaitu pengurus BAZNAS Kabupaten Gresik 
mendatangi para muzakki dan donatur yang akan menyalurkan zakat, infak dan shadqahnya.

Adapun realisasi dari program-program unggulan yang telah dilakukan BAZNAS Kabupaten Gresik yang merupakan realisasi penyaluran ZIS. Berikut ini realisasi penyaluran ZIS untuk program unggulan tahun 2012 antara lain:

a. Pertama, Gresik Cerdas. Melalui program Gresik Cerdas BAZNAS memberikan beasiswa kepada siswa SD, SMP dan SMA yang berprestasi akan tetapi mereka mempunyai latar belakang ekonomi kurang mampu. Mereka masing- masing mendapatkan Rp. 300 ribu untuk 40 siswa SD, Rp. 400 ribu untuk 17 siswa SMP dan Rp. 500 ribu untuk 9 siswa.

b. Kedua, Gresik Sehat. Bekerjasama dengan BAZ Jatim, BAZNAS Kabupaten Gresik mengadakan tujuh kali pengobatan gratis yang dilakukan di beberapa kecamatan, seperti Kecamatan Bungah, Benjeng, Dukun, Sidayu, Duduk Sampeyan, Driyorejo, Wringin Anom. Dana yang disalurkan sebesar Rp. 26.798.500,- Dalam kegiatan pengobatan gratis, salah seorang warga mengungkapkan harapannya kepada BAZNAS Kabupaten Gresik, menurutnya, kiranya kegiatan ini tidaklah hanya cukup sekali untuk satu desa, namun harapannya bisa ada penambahan kuota untuk tiap desa.

c. Ketiga, Gresik Peduli. Memberikan bantuan langsung kepada 1000 kaum fakir, miskin dan anak yatim. Selain itu juga memberikan bantuan air bersih yang diberikan kepada masyarakat kecamatan Cerme, serta pemberian bantuan kepada 26 orang ibnu sabil. Dana yang disalurkan sebesar Rp.263.237.000,-.

d. Keempat, Gresik Taqwa. Melalui program ini (berupa bantuan sosial keagamaan) BAZNAS Kabupaten Gresik memberikan bantuan untuk mushalla, pesantren dan tali asih Huffaz\}. Dana yang disalurkan dalam program kerja Gresik Taqwa ini sebesar Rp.46.550.000,-

Beberapa bentuk bantuan di atas membuktikan bahwa dengan dengan program kerja unggulan yang dilakukan 
BAZNAS Kabupeten Gresik telah mampu memberdayakan ekonomi umat Islam di wilayah Kabupaten Gresik. Dengan demikian dapat memberikan dan menumbuhkan kepercayaan kepada para muzakki yang pada akhirnya berpengaruh pada peningkatan jumlah muzakki. Melalui realisasi berbagai program yang telah dilaksanakan oleh BAZNAS Kabupaten Gresik, saat ini tercatat peningkatan jumlah muzakki yang cukup memuaskan dan membanggakan khususnya bagi pengelola BAZNAS Kabupaten Gresik.

Sejak berkembangnya BAZNAS Kabupaten Gresik tahun 2017, berbagai program kerja yang sudah dijalankan sudah bisa dinilai bagus, akan masih harus terus dimaksimalkan untuk tetap meningkatkan kesadaran muzakki untuk berzakat sehingga meningkat pula jumlah muzakki BAZNAS Kabupaten Gresik meskipun ada beberapa catatan yang harus di perbaiki sebagaimana yang peneliti tulis di analisis bagian pertama.

\section{Strategi BAZNAS Gresik dalam Mendapatkan Muzakki}

Posisi muzakki merupakan posisi yang sangat penting di BAZNAS, karena muzakki merupakan urat nadi dari lembaga zakat. Oleh karena itu kepercayaan muzakki menjadi hal yang penting untuk dijaga oleh BAZNAS karena Muzakki mempunyai peran untuk mendukung segala program yang dijalankan oleh BAZNAS. Oleh karena itu, kesadaran memerlukan ruang cipta, ia tidak bisa datang sendiri. Berbagai kalangan masyarakat, ulama, tokoh masyarakat dan pemerintah harus ikut terjun dalam menciptakan berbagai strategi pendekatan yang dapat menumbuhkan kepercayaan dan mampu mewujudkan lembaga pengelola zakat yang amanah, kredibel, akuntabel dan profesional.

Untuk menguatkan kepercayaan muzakki, BAZNAS merencanakan strategi untuk menyusun program yang dinilai kemudian dapat menumbuhkan kepercayaan muzakki sehingga mereka mau menyalurkan zakatnya melalui BAZNAS. Dengan demikian strategi yang diterapkan oleh sebuah organisasi atau lembaga yang disusun dengan baik dapat memberikan sumbangan terhadap kesuksesan organisasi. Sebaliknya, jika 
strategi tidak disusun dengan baik maka akan membawa organisasi atau lembaga mengarah pada kegagalan yang akan berdampak buruk bagi organisasi tersebut. Adapun perumusan dari rencana startegi BAZNAS Kabupaten Gresik adalah sebagai berikut:

1. Menjadikan BAZNAS Kabupaten Gresik sebagai organisasi yang diperhitungkan. BAZNAS Kabupaten Gresik harus menerapkan strategi untuk peningkatan kepercayaan yaitu dengan memperkuat sisi kelembagaan dengan menyusun visi dan misi BAZNAS Kabupaten Gresik serta memperkuat sistem organisasi dengan meningkatkan peran masingmasing departemen menjadi satu-satunya badan pengelola zakat yang amanah dan profesional di wilayah Kabupaten Gresik

2. Menjadikan BAZNAS Kabupaten Gresik sebagai pusat pelayanan zakat untuk masyarakat yang populis. Pelayanan terhadap muzakki dan mustahiq adalah aspek yang sangat penting dalam pengelolaan ZIS. Sebuah produk bisa berupa item yang memiliki fisik seperti modal, atau yang tidak memiliki fisik seperti jasa-jasa konsultasi pembinaan mustahiq. Pelayanan yang diberikan harus bisa memberikan kepuasan, baik bagi muzakki dan mustahiq BAZNAS Kabupaten Gresik.

3. BAZNAS Kabupaten Gresik harus gencar dalam meningkatkan sosialisasi, memberikan pemahaman terkait dengan pentingnya zakat. Sehingga BAZNAS Kabupaten Gresik di mata masyarakat menjadi badan pengelola serta pelayanan zakat yang terpercaya.

4. Menjadikan BAZNAS Kabupaten Gresik sebagai badan yang mampu melayani kebutuhan masyarakat duafa dan mustahiq dalam segala bidang.

Melalui berbagai program unggulan yang direncanakan dalam setiap tahunnya, BAZNAS Kabupaten Gresik menumbuhkan dan mewujudkan kasih sayang sesama serta solidaritas yang merupakan manifestasi tolong menolong. Mengembangkan tanggung jawab dan menumbuhkembangkan stabilitas kehidupan sosial, ekonomi, pendidikan dan 
mencerdaskan kehidupan bermasyarakat dengan penuh keberkahan.

Dalam upaya meningkatkan peran ZIS, BAZNAS Kabupaten Gresik menggandeng BAZNAS Provinsi Jawa Timur dan BAZ Kecamatan Sangkapura melaksanakan Bakti Sosial si Pulau Bawean yang terletak sekitar 80 mil laut dari Ibukota Kabupaten Gresik. Tim mereka memberikan bantuan untuk para duafa, anak yatim, masjid di Pulau Bawean serta mengadakan pengobatan gratis

Sehubungan dengan hal itu, maka zakat dapat berfungsi sebagai salah satu sumber dana sosial-ekonomi bagi umat Islam. Artinya pendayagunaan zakat yang dikelola oleh BAZNAS tidak hanya terbatas pada kegiatan/program-progam tertentu saja, tetapi dapat pula dimanfaatkan dalam program ekonomi umat, seperti dalam program pengentasan kemiskinan dan pengangguran dengan memberikan zakat produktif kepada mereka yang memerlukan sebagai modal usaha

Dalam melakukan aktifitas penghimpunan, BAZNAS Kabupaten Gresik tidak hanya melakukan kerjasama dengan para PNS saja, akan tetapi juga menjalin kerjasama dengan perusahaan baik dalam CSR (Coorporate Social Responsibility) maupun penghimpunan dana zakat, infaq dan sadaqah (ZIS) karyawan, di antaranya seperti: PT. Petrokimia Gresik, PT. Semen Gresik, PT. MIGAS Gresik.

\section{Analisis Efektifitas Pendekatan Public Relations BAZNAS Pada Peningkatan Kesadaran Muzakki di Gresik}

Strategi yang dijalankan oleh BAZNAS Kabupaten Gresik untuk menjalin hubungan yang baik dengan lingkungan akan memberi dampak baik bagi lembaga itu sendiri. Lembaga akan terhindar dari masalah-masalah yang timbul dari dalam lembaga maupun dari lingkungan sekitar yang menyebabkan produktifitas lembaga terganggu. Secara garis besar, hubungan komunitas atau lingkungan ini merupakan upaya untuk membantu menciptakan kondisi operasional yang kondusif. 
Hubungan yang dibangun antara lembaga dengan komunitasnya serta bagaimana perhatian pihak manajemen untuk mengelola berbagai sumber daya yang dimiliki agar bisa dioptimalkan dalam mencapai tujuan lembaga.

Agar tujuan-tujuan perusahaan tercapai, maka dibutuhkan strategi yang jitu dari divisi yang menangani fungsi Public Relations dalam suatu organisasi perusahaan. Strategi tersebut digunakan untuk menggarap persepsi para stakeholders, baik internal maupun eksternal agar mendukung lembaga dalam mencapai tujuan-tujuannya. Dengan strategi yang tepat pula, perusahaan akan dapat melakukan efisiensi dana dan tenaga serta dapat mewujudkan tujuan yang telah ditetapkan dengan tepat.

Besarnya potensi zakat di BAZNAS Kabupaten Gresik, menjadi tantangan bagi BAZNAS Kabupaten Gresik dalam melakukan penghimpunan dana. Oleh karena itu, menjadi tanggungjawab Public Relations untuk meningkatkan kepercayaan masyarakat kepada lembaga. Jika masyarakat percaya kepada lembaga, maka akan ada lebih banyak lagi muzakki dan donatur yang menyalurkan zakat atau dana kepada BAZNAS Kabupaten Gresik.

Karena Public Relations ini mempunyai pengaruh yang sangat besar terhadap peningkatan jumlah muzakki, maka BAZNAS Kabupaten Gresik mempunyai langkah-langkah strategis yang hingga saat ini dijalankan oleh Public Relations BAZNAS Kabupaten Gresik yaitu di antaranya mengoptimalkan sosialisasi informasi BAZNAS melalui media seperti, spanduk, sticker, website zakat online, media sosial, maupun dengan menjalin partnership dengan sejumlah media elektronik serta melakukan penyuluhan/audiensi.

1. Penyuluhan/ Audiensi

Penyuluhan atau audiensi merupakan bentuk sosialisasi dengan pertemuan langsung antara si penyuluh dan penerima informasi. Pertemuan secara langsung sangat efektif untuk menciptakan kesepahaman dan mengurangi 
resiko terjadinya kesalahpahaman atau miskomunikasi antara penyampai informasi dan penerima informasi.

Jika informasi tersebut menggunakan media lain mungkin akan menimbulkan pertanyaan di benak penerima informasi tentang, apa, bagaimana, kapan dsb. sedangkan mereka tidak akan menemukan jawaban dari semua itu dan mungkin akan muncul kesalah pahamaan antara pemberi informasi dan penerima informasi. Oleh karena itu pertemuan langsung sangat memberikan pengaruh yang berarti karena dari sana bisa terjadi diskusi, pertukaran pikiran, argumen dan bisa menjawab secara langsung apa yang menjadi pertanyaan di benak masyarakat.

Hal ini sejalan dengan Muhamad Hasan yang menyatakan bahwa tatap muka adalah metode sosialisasi yang lazim dilakukan. karena tatap muka adalah kegiatatan memberikan motivasi dengan cara berhadapan muka secara langsung antara penyuluh dan peserta penyuluh dengan pesan tertentu. Karena persoalan zakat ini adalah permasalahan yang sangat kompleks, disebabkan adanya bebagai pendapat yang telah berkembang sepanjang sejarah hukum. ${ }^{11}$

Kepercayaan masyarakat Gresik kepada BAZNAS Kabupaten Gresik meningkat setiap tahunya, hal ini bisa dilihat pada data BAZNAS Kabupaten Gresik dimana yang paling rendah adalah pada tahun 2010 dimana muzakki hanya berjumlah 100 orang kemudian mengalami kenaikan sampai pada tahun 2016.

Tabel 4.1

Data Jumlah Muzakki Tahun 2010-2016

${ }^{11}$ Muhamad Hasan, Manajemen Zakat: Model Pengelolaan Yang Efektif (Yogyakarta: Idea Press, 2011).64 


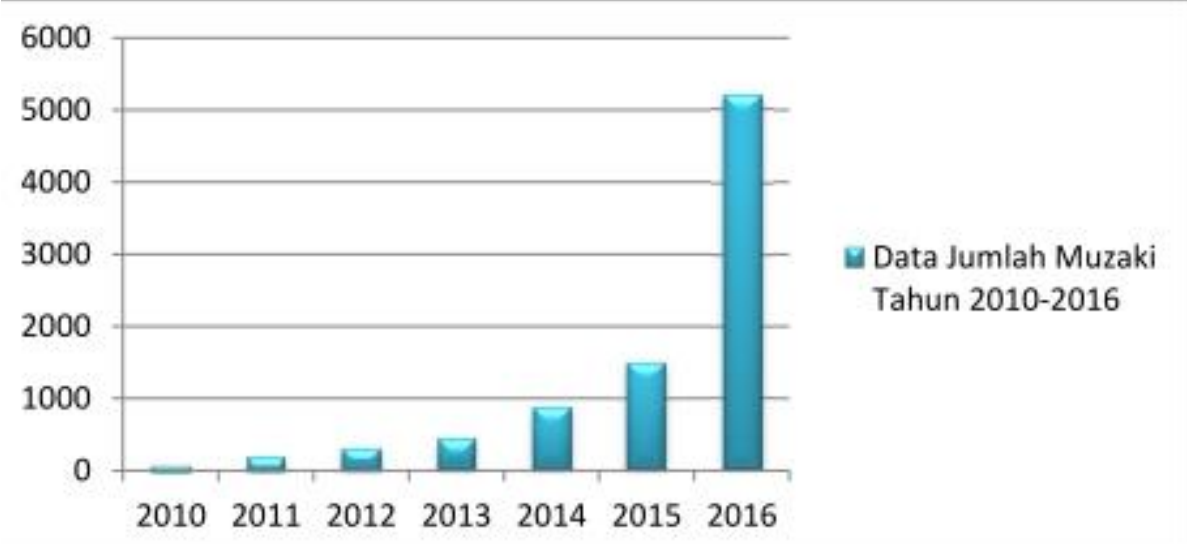

Dari table di atas bisa kita lihat bahwasanya peningkatan muzakki dari tahun 2015 ke 2016 meningkat sangat signifikan. Hal ini dikarenakan pada tahun tersebut dilaksanakan sosialisasi yang berbentuk audiensi ke Dinas Pendidikan, dan setelah sosialisasi tersebut dilaksanakan, 62 sekolah menyalurkan zakatnya ke BAZNAS Kabupaten Gresik.

Audiensi tidak hanya dilakukan di lingkup SKPD, BAZNAS Kabupaten Gresik juga melakukan audiensi ke sekolahsekolah dan perusahaan. Dari 100 perusahaan yang dikunjungi BAZNAS Kabupaten Gresik untuk audiensi pada tahun 2015, ada 5 perusahaan mempercayakan Zakatnya untuk dikelola oleh BAZNAS. sedangkan yang lainya bersedia memberikan infak dan sedekah saja. Adapun 5 perusahaan tersebut adalah:

a. PT Gresik Migas berzakat senilai Rp. 1.273.969.976,-

b. Bank Jatim Cab Gresik berzakat senilai 3.994.500,-

c. PT Tri Jaya Graha Sentosa Abadi berzakat senilai Rp. 20.000.000,-

d. PT Tulen Graha Amerta berzakat senilai Rp. 10.000.000,-

e. BDI Job Pert Petro China East Java berzakat senilai Rp. 5.603.040,-

Ketika menginjak tahun 2016, Perusahaan yang menyalurkan Zakat menurun dan hanya dua perusahaan yang tetap menyalurkan zakatnya yaitu PT Tulen Graha Amerta, senilai Rp 10.000.000,- dan PT Gresik Migas senilai 
Rp. 3.895.000,- hal Ini menandakan bahwa BAZNAS Kabupaten Gresik kurang mampu untuk mempertahankan muzakki. Jika saja sosialisasi yang berbentuk silaturahmi ke setiap SKPD juga di terapkan di setiap Perusahaan, dan komunikasi diantara mereka terjaga, maka penurunan muzakki ini akan bisa dihindari.

Selain ke perusahaan-perusahaan yang berkembang, sosialisasi juga dilaksanakan di masyarakat umum, dalam hal ini BAZNAS Kabupaten Gresik merencanakan sosialisasi zakat mal ke beberapa masjid di kota Gresik. Sekitar 10 UPZ yang sudah terbentuk di masjid- masjid tersebut mereka bertugas melaporkan zakat yang diperoleh dari masyarakat setiap tahun dan biasanya pada bulan Ramadan.

2. Sosialisasi melalui media cetak.

Sosialisasi zakat mal yang dilakukan BAZNAS melalui media cetak juga sudah bagus, BAZNAS memiliki majalah Tazkiyah yang terbit tiap triwulan yang disebarkan ke tiap-tiap SKPD walaupun pembagianya tidak ke setiap orang, setidaknya satu sudah mewakili untuk memberikan informasi kegiatan apa saja yang telah dilakukan BAZNAS Kabupaten Gresik sehingga bisa diasumsikan bahwa semua PNS di lingkup kota Gresik telah mengetahui bagaimana BAZNAS Kabupaten Gresik mengelola zakatnya dan kemana saja didistribusikan. Penyebaran pamplet, brosur dan banner juga sudah sering dilakukan. diharapkan dengan ini para muzakki semakin yakin terhadap sasaran zakat yang telah mereka keluarkan. Brosur MZS (Menghitung Zakat Sendiri) disebar setiap kali sosialisasi dilakukan.

Pengiriman proposal dilakukan BAZNAS baik di bulan Ramadan ataupun di luar bulan Ramadan. Dari 100 perusahaan yang dikunjungi BAZNAS Kabupaten Gresik untuk pengiriman proposal, 55 perusahaan yang menyalurkan dana infak kepada BAZNAS Kabupaten Gresik pada bulan Ramadan dan 6 perusahaan yang rutin menyalurkan infak tiap bulan. Sedangkan yang menyalurkan dana zakat dikarenakan pengiriman proposal masih belum ada. 
3. Sosialisasi melalui media elektronik

Sosialisasi yang dilakukan melalui media elektronik juga sudah pernah dikakukan oleh BAZNAS Kabupaten Gresik namun belum berjalan maksimal, mengingat mahalnya biaya siaran melalui dua alat elektronik tersebut, pernah sekali melakukan diskusi di salah satu stasiun televisi TV9 dan biaya siaran dalam waktu 30 menit saja sudah harus mengeluarkan biaya 5 juta, mengingat biaya dan efektifitasnya tidak sebanding, maka siaran TV ini tidak dilakukan lagi, dan beralih ke media sosialisasi lainya yang memiliki pengaruh yang lebih efektif.

Sedangkan sosialisasi melalui radio dilaksanakan setahun sekali yaitu ketika bulan Ramadan di salah satu stasiun radio Gresik yang terkenal yaiu Swara Giri FM. Nampakya hal in kurang efektif sebagaimana yang kia tahu tidak banyak orang yang mendengarkan radio akhir-akhir ini. mereka lebih memilih menonton televisi atau membuka situs melalui internet.

Melihat pelaksanaan sosialisasi yang dilakukan BAZNAS Kabupaten Gresik diatas, penulis menemukan bahwa model sosialisasi yang digunakan BAZNAS Kabupaten Gresik sudah sesuai dengan standar yang menjadi acuan Kemenag dalam mensosialisasikan zakat. namun memang ada satu poin yang masih belum dilakukan BAZNAS Kabupaten Gresik sampai saat ini yaitu seminar.

Kegiatan sosialisasi yang dilakukan BAZNAS Kabupaten Gresik ini bukan hanya untuk meningkatkan kesadaran masyarakat dalam membayar zakat. namun juga untuk mengingatkan masyarakat muslim untuk selalu menjaga pelaksanaan rukun islam yang ketiga ini. bentuk pengingat tersebut banyak ragamnya dari silaturahim ke setiap SKPD sampai dengan banner-banner yang di pasang di tempattempat umum.

Untuk menjaga hubungan baik antara BAZNAS dan Muzakki, BAZNAS melakukan silaturahim ke SKPD secara rutin. Namun hal ini masih belum diterapkan di perusahaanperusahaan sehingga ketika sosialisasi yang pertama kali 
dilakukan, mereka membayarkan zakatnya melalui BAZNAS, namun setelah sosialisasi tidak dilakukan lagi, maka mereka juga tidak menyalurkan dana zakatnya lagi.

Walaupun jumlah muzakki mengalami peningkatan setiap tahun, namun peningkatan kepercayaan masyarakat non PNS masih sangat minim. hal ini dapat di tunjukan pada tingkat penurunan yang sangat tajam muzakki yang berasal dari Perusahaan

Tabel $4.2^{12}$

Data Perolehan Zakat dari PNS dan Perusahaan

\begin{tabular}{|l|l|l|}
\hline Tahun & $\begin{array}{l}\text { Zakat Personal } \\
\text { (PNS) }\end{array}$ & $\begin{array}{l}\text { Zakat } \\
\text { Perusahaan }\end{array}$ \\
\hline 2015 & $780.871 .150,-$ & $1.309 .573 .016,-$ \\
\hline 2016 & $1.434 .173 .974,-$ & $10.000 .000,-$ \\
\hline
\end{tabular}

Jika kegiatan sosialisasi yag berupa silaturahim ini terus menerus dilakukan maka tidak menutup kemungkinan bahwa BAZNAS Kabupaten Gresik bisa dapat mempertahankan muzakki dan membangun kepercayaan masyarakat sehingga bisa mencapai target presentase wajib zakat di kota Gresik.

Dari Hasil penelitian diatas, kita dapat mengetahui bahwasanya BAZNAS Kabupaten Gresik sudah sangat maksimal untuk melakukan sosialisasi di kalangan masyarakat baik PNS maupun non PNS, namun hambatan pasti ada di setiap kegiatan karena hidup tidak akan bebas dari resiko, apalagi dalam sosialisasi zakat.

\section{Penutup}

Berdasarkan penelitian yang dilakukan mengenai Strategi Pendekatan Public Relations BAZNAS Gresik dalam Meningkatkan Pendapatan maka dapat diambil kesimpulan sebagai berikut : pertama, Muzakki di Kabupaten Gresik belum memiliki kesadaran tinggi dalam mengeluarkan zakat, sebab dari jumlah muzakki sebanyak 5200, zakat yang terkumpul

\footnotetext{
12 BAZNAZ Kabupaten Gresik, Laporan Pertanggung Jawaban BAZNAZ Kabupaten Gresik.12
} 
hanya Rp 5.088.758.446. Padahal jika muzakki sejumlah tersebut sadar mengeluarkan zakat maka akan terkumpul zakat sebesar Rp 10.088.758.446. Kedua, strategi BAZNAS Kabupaten Gresik dalam meningkatkan jumlah muzakki antara lain menjadikan BAZNAS Kabupaten Gresik sebagai organisasi yang diperhitungkan, sebagai pusat pelayanan zakat untuk masyarakat yang populis, sebagai badan yang mampu melayani kebutuhan masyarakat d\}uafa dan mustah\}iq dalam segala bidang, sebagai pusat pemberdayaan ekonomi umat, mensejahterakan masyarakat d\}uafa di wilayah Kabupaten Gresik, dan menjadikan motivator bagi muzakki untuk menghitung besar zakatnya. Rencana strategis tersebut di atas masih belum tertuang dalam bentuk perumusan strategi secara tertulis, semua yang direncanakan untuk kemajuan dan perkembangan saat ini masih terumus dalam rencana program kerja tahunan BAZNAS Kabupaten Gresik. Ketiga, Public Relations ini mempunyai efektifitas dalam peningkatan jumlah muzakki, maka BAZNAS Kabupaten Gresik mempunyai langkah-langkah strategis yang hingga saat ini dijalankan oleh Public Relations BAZNAS Kabupaten Gresik yaitu di antaranya mengoptimalkan sosialisasi informasi BAZNAS melalui media seperti, spanduk, sticker, website zakat online, media sosial, maupun dengan menjalin partnership dengan sejumlah media elektronik serta melakukan penyuluhan/audiensi

Bentuk sosialisasi selain audiensi dan silaturahim, kebanyakan dilakukan ketika menjelang bulan Ramadan. Menurut Bapak Khalik, selaku devisi pengumpulan, Ramadan adalah bulan panenya lembaga- lembaga zakat. namun pengeluaran zakat mal tidak terikat pada bulan Ramadan , karena batas pengeluaran zakat mal itu terhitung ketika harta seseorang sudah mencapai nisab dan sudah mencapai satu tahun. Jadi ketika mencapai nisabnya itu di luar bulan Ramadan dan utuh selama satu tahun, maka tentu saja ia harus mengeluarkan zakatnya waktu itu juga tanpa menunggu bulan Ramadan tiba. Maka hal ini perlu dipertimbangkan. Melihat pelaksanaan sosialisasi yang dilakukan BAZNAS Kabupaten Gresik diatas, penulis menemukan bahwa model sosialisasi 
yang digunakan BAZNAS Kabupaten Gresik sudah sesuai dengan standar yang menjadi acuan Kemenag dalam mensosialisasikan zakat. namun memang ada satu poin yang masih belum dilakukan BAZNAS Kabupaten Gresik sampai saat ini yaitu seminar. Kegiatan sosialisasi yang dilakukan BAZNAS Kabupaten Gresik ini bukan hanya untuk meningkatkan kesadaran masyarakat dalam membayar zakat. namun juga untuk mengingatkan masyarakat muslim untuk selalu menjaga pelaksanaan rukun islam yang ketiga ini. bentuk pengingat tersebut banyak ragamnya dari silaturahim ke setiap SKPD sampai dengan banner-banner yang di pasang di tempattempat umum.

\section{Daftar Pustaka}

BAZNAZ Kabupaten Gresik. Laporan Pertanggung Jawaban BAZNAZ Kabupaten Gresik. Gresik, n.d.

Effendy, Onong. Ilmu Teori Dan Filsafat Komunikasi. Bandung: PT.Rosdakarya, 2000.

Hasan, Muhamad. Manajemen Zakat: Model Pengelolaan Yang Efektif. Yogyakarta: Idea Press, 2011.

M, Ahmad, and Saefuddin. Ekonomi Dan Masyarakat Dalam Prespektif Islam. Jakarta: CV. Rajawali, 1987.

Mulyana, Deddy. Metodologi Penelitian Kualitatif. Bandung: PT Remaja Rosdakarya, 2002.

Qadir, Abdurrachman. Zakat (Dalam Dimensi Mahdah Dan Sosia). Jakarta: Raja Grafindo Persada, 2001.

Rumanti, Sr. Maria Assumpta. Dasar-Dasar Public Relations Teori Dan Praktik. Jakarta: PT. Grasindo, 2002.

Ruslan, Rosady. Metode Penelitian PR Dan Komunikasi. Jakarta: PT. RajaGrafindo, 2003.

“Sejarah BAZNAZ Gresik." http://baznasgresik.com/sejarah/. 